\title{
DETERMINATION AND ANALYSIS OF KINETIC PARAMETERS OF HETEROTROPHIC BACTERIA IN MATHEMATICAL SIMULATION
}

\author{
LV, W. L. ${ }^{1,2,3}$ - GOU, S. Z. ${ }^{4}$ - CHEN, Y. W. ${ }^{1,2,3}-$ SUN, Y. F. ${ }^{1,2}-$ GAO, X. D. ${ }^{1,2}-$ TAN, Z. L. ${ }^{1,2}-$ \\ LI, X. D. ${ }^{1,2 *}$ \\ ${ }^{I}$ Key Laboratory of Environmental and Applied Microbiology, Chengdu Institute of Biology, \\ Chinese Academy of Sciences \\ No. 9 The 4th Section of South Renmin Road, 610041 Chengdu, China \\ (phone: +86-28-8289-0289; fax: +86-28-8289-0288) \\ ${ }^{2}$ Environmental Microbiology Key Laboratory of Sichuan Province, Chengdu Institute of \\ Biology, Chinese Academy of Sciences \\ No. 9 The 4th Section of South Renmin Road, 610041 Chengdu, China \\ (phone: +86-28-8289-0289; fax: 028-8289-0288) \\ ${ }^{3}$ University of Chinese Academy of Sciences \\ No. 19(A) Yuquan Road, Shijingshan District, 100049 Beijing, China \\ (phone: +86-10-8825-6030; fax: +86-10-8825-6006) \\ ${ }^{4}$ Chengdu Vocational \& Technical College of Industry \\ No. 818 Daan Road, 610218 Chengdu, China \\ (phone: +86-28-6445-8874; fax: +86-28-6445-8861) \\ *Corresponding author \\ e-mail: lixd@cib.ac.cn; phone: +86-28-8289-0289; fax: +86-28-8289-0288 \\ (Received 25 $5^{\text {th }}$ Aug 2017; accepted $14^{\text {th }}$ Dec 2017)
}

\begin{abstract}
This paper studied the Anaerobic-Anoxic-Oxic $\left(\mathrm{A}_{2} / \mathrm{O}\right)$ process of a city sewage treatment plant in Sichuan Province, China. We established a mathematical model of sewage treatment plant. The yield coefficient of heterotrophic bacteria $(\mathrm{YH})$ in $\mathrm{A}_{2} / \mathrm{O}$ process was 0.65 ; maximum specific growth rate $(\mathrm{uH})$ of $8.6 \mathrm{~d}^{-1}$; attenuation coefficient $(\mathrm{bH})$ of $3.5 \mathrm{~d}^{-1}$. Compared with the recommended values reported in the literature, the results showed that the yield coefficient of heterotrophic bacteria measured by this method was consistent with the recommended value and the maximum specific growth rate and attenuation coefficient were higher than the recommended value. Different water qualities of different processes and heterotrophic bacteria in the activity are not the same. So the determination of the results will be different. Using the Electrolytic Respirometer developed by Bioscience Incorporation (BI-2000), the microbial oxygen uptake rate (OUR) curve is more accurate, the sampling frequency is higher, the sampling point is more, the judgment of the logarithmic period is more accurate, the test result is more reliable and the sewage treatment plant of the upgrade and simulation to optimize the operation to provide a theoretical basis.
\end{abstract}

Keywords: anaerobic-anoxic-oxic, kinetic parameters $(Y H, u H, b H)$, mathematical simulation, OUR curve

\section{Introduction}

$\mathrm{A}_{2} / \mathrm{O}$ Activated Sludge Process for the degradation of organic pollutants mainly rely on heterotrophic bacteria, the degradation process of activated sludge system mainly includes microbial decomposition of organic pollutants, microbial anabolism, selfdecomposition and heterotrophic microbes as the main microorganisms in the activated sludge system. In the mathematical model of sewage treatment, these processes can describe by the kinetic parameters such as the yield coefficient of heterotrophic bacteria, 
the growth rate and the attenuation is coefficient. Therefore, it is very important to determine the kinetic parameters of heterotrophic bacteria. As a method recommended by International Water Association (IWA), respiration measurement has applied successfully to the determination of stoichiometry and kinetic parameters of wastewater (Smriga et al., 2016) and for the determination of Chemical Oxygen Demand (COD) components (Wu et al., 2016).

At present, in most models such as Active Sludge Model 1 (ASM1), Active Sludge Model 2d (ASM2d) in the dynamic parameters of the recommended value and the recommended value has determined by the founder of the model software, according to their region of water quality and used Sewage treatment process to determine the results obtained. Due to differences in Chinese diet and differences in sewage treatment methods lead to differences in water quality components and microbial biochemical reaction environment. So the recommended value in the general model in China's application there is a certain irrational (Wu et al., 2016).

In this experiment, the $\mathrm{A}_{2} / \mathrm{O}$ process of a city sewage of treatment plant in Sichuan Province is used as the research object, by using an electrolyte respirator BI-2000. It is determined the wastewater treatment plant yield coefficient $\mathrm{A}_{2} / \mathrm{O}$ process in heterotrophic bacteria and the maximum growth of the attenuation coefficient Rate, which provides a basis for the determination and simulation of $\mathrm{A}_{2} / \mathrm{O}$ process model parameters.

\section{Materials and methods}

The experiment was conducted using the Electrolytic Respirometer (BI-2000) developed by Bioscience Incorporation, USA (Fig. 1).

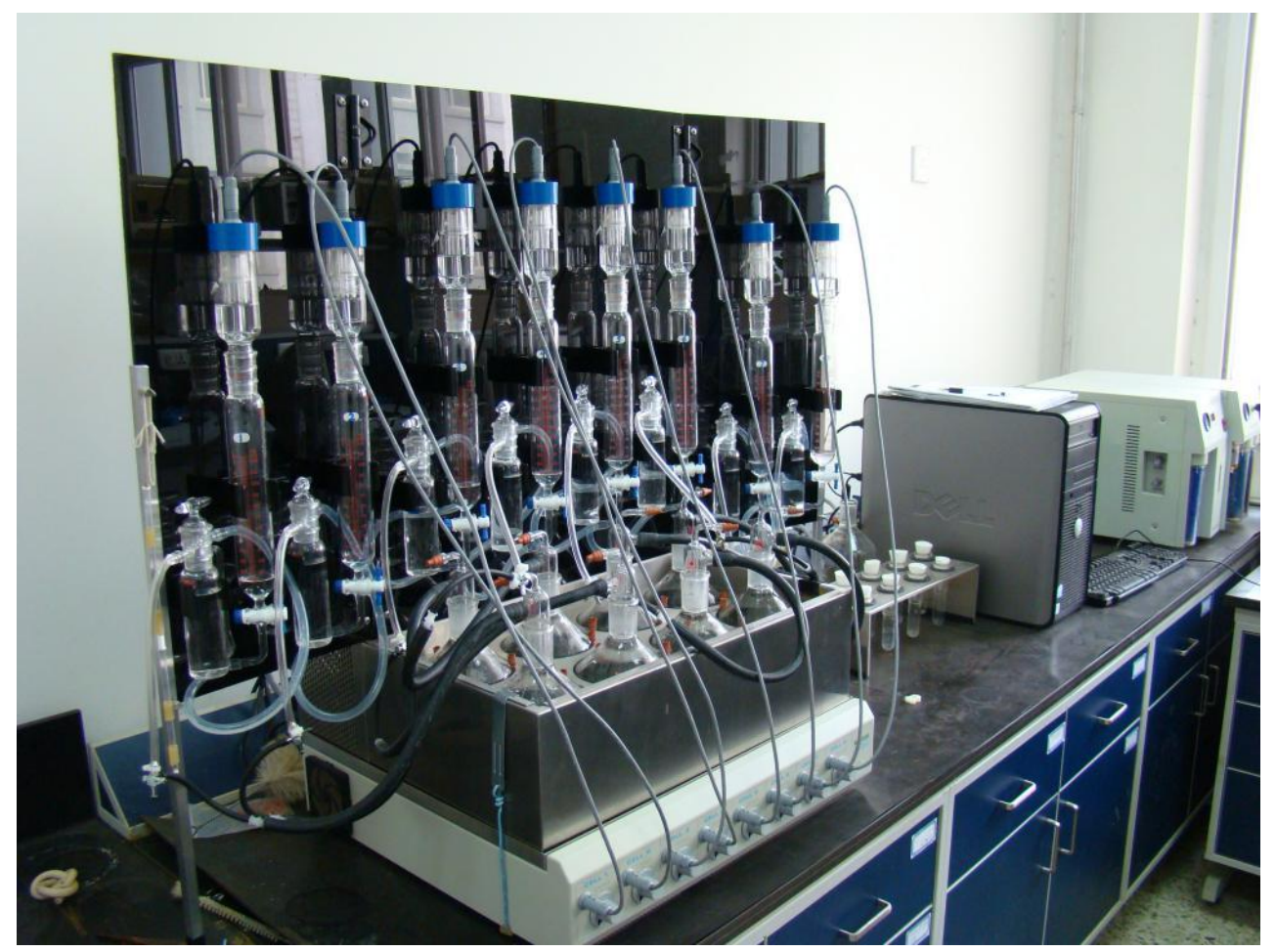

Figure 1. BI-2000 electrolytic respirator 
Because the electrolyte breathing apparatus has a higher test accuracy and test frequency $-0.05 \mathrm{~h}$ can get a Biochemical Oxygen Demand (BOD). In addition, by improving the test frequencies in a more abundant data based on the first-order dynamic equation fitting and we make the test results obtained more accurate. Electrolyte respirator is mainly composed of $1 \mathrm{~L}$ reactor, electrolysis unit, $\mathrm{CO}_{2}$ trap and related software. It is shown in Figure 2 (Karanasios et al., 2016). The determination principle of "how much oxygen consumption, how much oxygen", the electrolyte breathing apparatus can accurately measure the oxygen consumption of microorganisms. The specific steps are used to take the appropriate volume of activated sludge and raw water mixed in a $1 \mathrm{~L}$ sealed reactor, the occurrence of biochemical reactions, consumption of oxygen and produce $\mathrm{CO}_{2}, \mathrm{CO}_{2}$ is loaded with $45 \% \mathrm{KOH}$ solution of the $\mathrm{CO}_{2}$ trap to absorb the pressure drop in the reactor. The pressure sensor detects this pressure change and turns on the power of the electrolysis unit, which produces oxygen to supplement the oxygen consumed by the reaction process and maintains the pressure balance inside and outside the reactor (Yang et al., 2016). The computer calculates the oxygen production of the electrolysis unit based on the amount of current and the turn-on time during the reaction, thereby obtaining the amount of oxygen consumed by the microorganisms in the test.

The solutions to configure in the test were $1 \mathrm{~mol} / \mathrm{L} \mathrm{H}_{2} \mathrm{SO}_{4}$ solution (electrolytic solution), $45 \% \mathrm{KOH}$ solution $\left(\mathrm{CO}_{2}\right.$ absorption solution). Before the test, first open the constant temperature water tank and magnetic stirrer preheat $2 \mathrm{~h}$. The reactor containing the reaction mixture, the nitrification inhibitor ATU and the magnetic stirring rotor is then preheated for a period to ensure that the temperature difference between outside and the inside of the reactor is uniform (Yuan et al., 2016). Then a $\mathrm{CO}_{2}$ trap equipped with a $\mathrm{KOH}$ solution and a reactor equipped with dilute sulfuric acid Liquid electrolysis unit assembled, connected to the line, and began to record data.

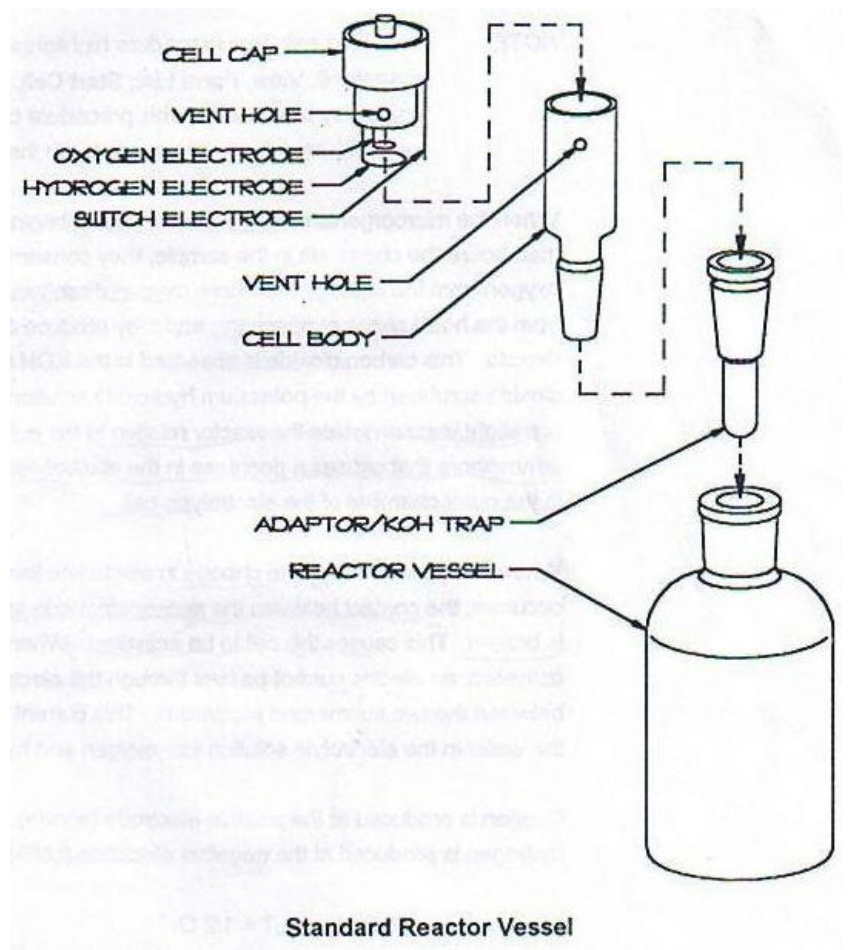

Figure 2. BI-2000 electrolyte breathing apparatus device map 


\section{Results}

\section{Heterotrophic decay coefficient bH determination}

There are two main recognized microbial attenuation theory: one is the traditional attenuation theory; the other is the theory of death regeneration.

Traditional attenuation theory thinks that the process of microbial attenuation in the process will use their internal storage of energy substances for breathing. After the death of microorganisms, the formation of cell residues (Xp). It does not take into account the decomposition of cells after death produced by other microorganisms' matrix Slowly biodegradable COD (Xs) (Xu et al., 2017). The Microbial growth and decay process will breathe oxygen consumption. When microorganisms consume Readily Biodegradable COD (Ss) and Slowly biodegradable COD (Xs), there is only the decay process that is microbial endogenous breathing consumption of oxygen.

The death regeneration theory suggests that the microbial attenuating part of the cell residue $X p, X p$ is a particulate non-biodegradable organic matter and can be used no longer. The amount of microbial reduce is another part of the decomposition produces slow biodegradable organic matter $\mathrm{Xs}, \mathrm{Xs}$ is hydrolyzed to produce new microorganisms for the growth of other microorganisms that is regeneration. When the matrix has consumed completely, the Ss formed by the hydrolysis of the attenuated product Xs become the matrix of the remaining microbial growth (Dorado et al., 2015). At the time the oxygen consumed is only caused by the Ss produced by this partial hydrolysis that is only depends on the growth of the heterotrophic bacteria.

The mathematical expression of death regeneration theory is as follows.

In the theory of death regeneration, the microorganisms are decomposed to form Xs; Xs hydrolyze to produce Ss for the growth of other microorganisms. Therefore, in the batch reactor, without the carbon source, microbial concentration change has expressed by Equation 1 (Domingo et al., 2017).

$$
\frac{d X_{H}}{d t}=-b_{H} \bullet X_{H}+\frac{S S}{K_{S}+S_{S}} \bullet u_{H} \bullet X_{H}
$$

The process of hydrolysis of Xs is relatively slow so the hydrolysis process is a velocity limiting process. When no carbon source added, Ss has obtained by hydrolysis of Xs and expressed by Equation 2..

$$
\frac{d S_{S}}{d t}=\frac{d X_{S}}{d t}=b_{H}\left(1-f_{p}\right) X_{H}
$$

The ratio of the activated biomass to the cell residue $\mathrm{Xp}$ in the fp-death regeneration mode is about 0.08 (Liu et al., 2017; Pisoeiro et al., 2017). If the Ss produced by the hydrolysis of Xs and the Ss consumed by the microorganisms are equal (Eqs. 3-6).

$$
\begin{gathered}
\frac{\mathrm{d} S_{\mathrm{S}} \text { Consumption }}{\mathrm{d} t}=\frac{d X_{S} \text { Produce }}{\mathrm{d} t} \\
-\frac{\mathrm{d} S_{S} \text { Consumption }}{\mathrm{d} t}=\frac{1}{Y_{H}} \bullet \frac{S_{S}}{K_{S}+S_{S}} \mathrm{u}_{H} \bullet X_{H}
\end{gathered}
$$




$$
\begin{gathered}
\mathrm{b}_{H}\left(1-f_{p}\right) X_{H}=\frac{1}{Y_{H}} \frac{S_{S}}{K_{S}+S_{S}} \bullet \mathrm{u}_{H} \bullet X_{H} \\
\mathrm{~b}_{H}\left(1-f_{p}\right) Y_{H} \bullet X_{H}=\frac{S_{S}}{K_{S}+S_{S}} \bullet \mathrm{u}_{H} \bullet X_{H}
\end{gathered}
$$

Equation 6 into Equation 1 gets Equation 7.

$$
\frac{\mathrm{d} X_{H}}{d t}=b_{H}\left[Y_{H}\left(1-f_{p}\right)-1\right] \bullet X_{H}
$$

When the $\mathrm{t}=0, \mathrm{XH}=\mathrm{XH}(0)$ and Equation 7 are integral, the microbial concentration of the $t$ moment can be obtained (Eq. 8).

$$
X_{H}(\mathrm{t})=X_{H}(0) e^{-b H\left[1-Y_{H}\left(1-f_{\mathrm{p}}\right)\right] t}
$$

The mathematical expression of the traditional attenuation model is as follows.

The traditional decay theory does not take into account the microbial decay after the decomposition of the formation of other microbial growth of the matrix of this process, the rate of heterotrophic bacteria decay (Eq. 9).

$$
\frac{\mathrm{d} X_{H}}{d t}=-b^{\prime}{ }_{H} \bullet X_{H}
$$

In Equation 9, b' $\mathrm{H}$ is the attenuation coefficient from the traditional theory, to score it $(E q .10)$.

$$
X_{H}(\mathrm{t})=X_{H}(0) \mathrm{e}^{-b^{\prime} H \bullet t}
$$

Contrast Equations 8 and 10 available (Eq. 11):

$$
b_{H}=b^{\prime} H /\left(1-Y_{H}\left(1-f_{p}\right)\right)
$$

According to the description of the traditional attenuation theory, the dissipation rate of dissolved oxygen in relation to the attenuation of heterotrophic bacteria is as follows (Eq. 12).

$$
\mathrm{r}(t)=\frac{d S_{O 2}}{d t}=-\left(1-f^{\prime}{ }_{\mathrm{p}}\right) \frac{d \mathrm{X}_{\mathrm{H}}}{d t}=-\left(1-f^{\prime}{ }_{p}\right) b^{\prime}{ }_{H} \bullet X_{H}
$$

Equation 10 into Equation 12 (Eq. 13):

$$
\mathrm{r}(t)=\frac{d S_{O 2}}{d t}=-\left(1-f^{\prime}{ }_{p}\right) b^{\prime}{ }_{H} \cdot X_{H}(0) \mathrm{e}^{-b^{\prime} H \cdot t}
$$


Take the logarithm of the above formula here (Eq. 14):

$$
\ln r(t)=\ln \left[\left(1-f^{\prime}{ }_{p}\right) b^{\prime}{ }_{H} X_{H}(0)\right]-b^{\prime}{ }_{H} \bullet \mathrm{t}
$$

It can be seen from the above formula that the natural logarithm of the dissolved sludge consumption rate with the activated sludge and the slope of the time-dependent curve of the activated sludge measured in the absence of a carbon source, which are the conventional attenuation coefficient (Mozumder et al., 2015; Wang et al., 2016). Hence, the first measurement the value of $\mathrm{bH}$ and $\mathrm{YH}, \mathrm{Value}$ get $\mathrm{bH}$ by calculated the formula.

Take the end of the mixture full of aeration in the aerobic tank of $\mathrm{A}_{2} / \mathrm{O}$ process, during the demonized water washed 3 times, standing for $30 \mathrm{~min}$, drained the supernatant; take the treated sludge into the breathing apparatus (Leyva-Díaz et al., 2015; Mampaey et al., 2013). To avoid nitrification affect the consumption of heterotrophic bacteria, add ATU (0.02 $\mathrm{g} / \mathrm{L}$ propylene thiourea), inhibit the activities of autotrophic bacteria and then add de-ionized water, began to measure the depletion of heterotrophic oxygen consumption curve.

According to Equation 14, use Ln(OUR) and time t to make a map, the slope of the straight line is the attenuation coefficient of the heterotrophic bacteria $u_{H}^{\prime}$. Under the same conditions, the average value has determined by Equation 11 bacteria attenuation coefficient $u_{H}$.

Under the same test conditions, the results of the four tests were as in Figure 3, the attenuation coefficient of the death regeneration model was $3.12 \mathrm{~d}-1,4.2 \mathrm{~d}-1,3.11 \mathrm{~d}-1$, 3.58 d-1 3.5 d-1 (Liu et al., 2017; Guimerà et al., 2016). Compared with the recommended value of the model, the analysis may be due to the differences in water quality and process differences.
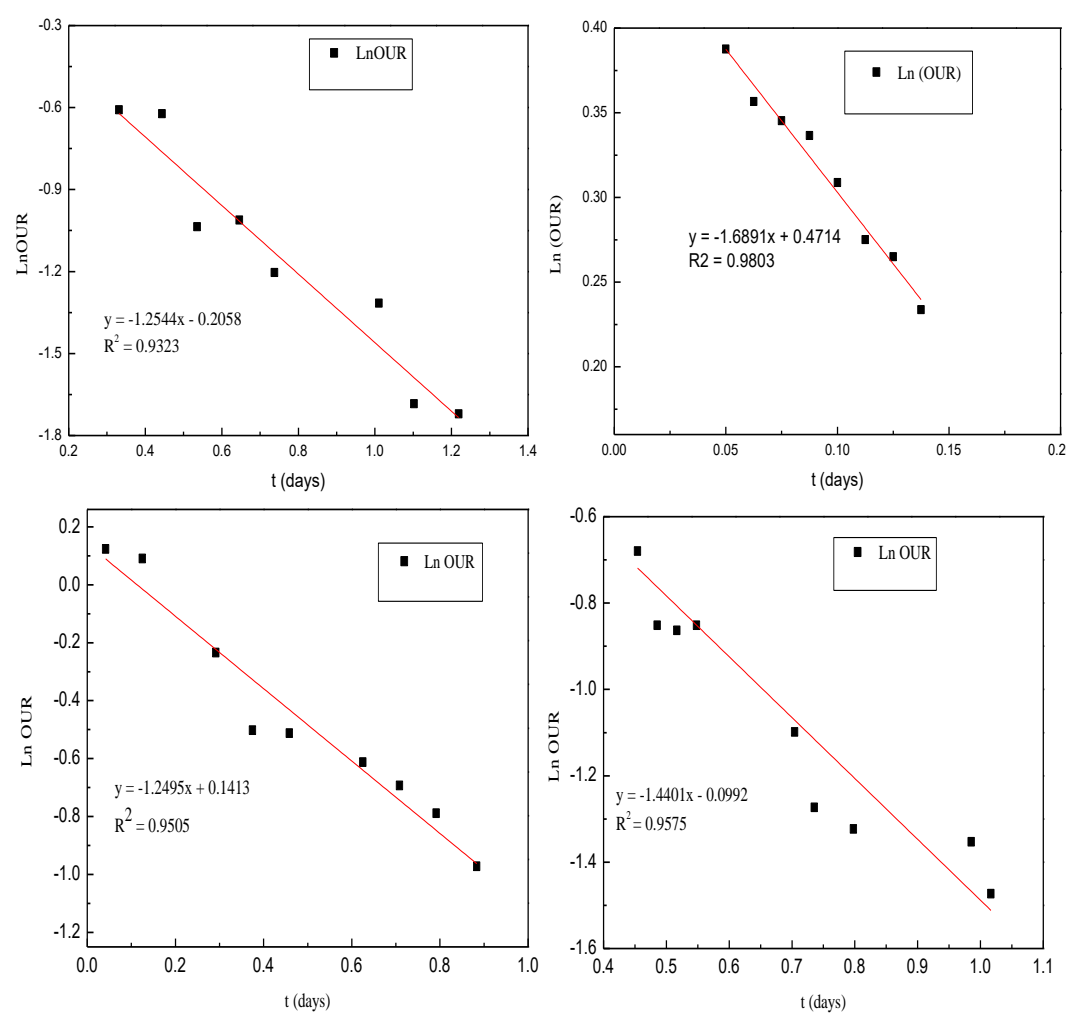

Figure 3. Determination of the traditional attenuation coefficient 
From Figure 3 we can see that $\operatorname{Ln}(\mathrm{OUR})$ is linearly fitted with time $\mathrm{t}$ and the slope is the traditional attenuation coefficient. From the above equations (Eqs. 2-11; Peng et al., 2017; Domingo-Félez $\mathrm{C}$ et al., 2017), we can see that the relationship between bH and the $\mathrm{bH}$ is $b_{H}=b_{H}^{\prime} /\left(1-Y_{H}\left(1-f_{p}\right)\right)$ and calculated according to this relationship get attenuation coefficient $\mathrm{bH}$, the results show in Table 1.

Table 1. Determination of attenuation coefficient of heterotrophic bacteria bH

\begin{tabular}{|c|c|c|c|}
\hline Number & $\boldsymbol{b}_{\boldsymbol{H}}{ }_{\boldsymbol{H}} / \boldsymbol{d} \mathbf{- 1}$ & $\boldsymbol{b}_{\boldsymbol{H}} / \boldsymbol{d} \mathbf{- 1}$ & \multirow{2}{*}{ Recommended value } \\
\hline 1 & 1.25 & 3.12 & \multirow{2}{*}{0.62} \\
\hline 2 & 1.69 & 4.20 & \\
\hline 3 & 1.25 & 3.11 & \\
\hline Average value & 1.44 & 3.58 & \\
\hline
\end{tabular}

\section{Determination of yield coefficient of heterotrophic bacteria}

The heterotrophic yield coefficient $(\mathrm{YH})$ is a relatively important stoichiometric factor. It not only affects the estimation of sludge yield and oxygen demand but also for certain wastewater components (e.g., biodegradable organic components $\mathrm{S}_{\mathrm{S}}$ and slow Speed biodegradable components $\mathrm{X}_{\mathrm{S}}$, etc.) and kinetic parameters (heterotrophic bacteria than the growth rate, attenuation coefficient) have an impact. Thus, YH is a very critical stoichiometric parameter and $\mathrm{YH}$ inaccurate results in errors in the calculation of other component parameters (Zięba and Janiak, 2017). Therefore, YH is a more critical parameter, the need for accurate determination (Qin et al., 2016). At present, the more mature method is intermittent activated sludge method and breathing measurement method.

According to the definition of $\mathrm{YH}$ that is in the activated sludge system, part of the soluble organic matter consumed in the sewage is used for the respiration of microorganisms, converted into $\mathrm{CO}_{2}$ and $\mathrm{H}_{2} \mathrm{O}$ and the other part is absorbed into the new cells by organic matter (Peng et al., 2017). As long as the intermittent measurement of microbial COD is in the closed system, the amount of soluble organic matter reduction, and the ratio is $\mathrm{YH}$ (Eqs. 18 and 19).

$$
\begin{gathered}
Y_{H}=\frac{\Delta C O D \text { Cell }}{\Delta C O D \text { Soluble }}=\frac{\Delta C O D-\int \mathrm{r}(\mathrm{t}) \mathrm{dt}}{\Delta C O D} \\
\Delta C O D=C O D_{1}-C O D_{2}
\end{gathered}
$$

In the above formula: $\mathrm{COD}_{1}$ is the initial COD in the mixture, $\mathrm{COD}_{2}$ is the COD in the mixed solution; $\triangle \mathrm{COD}$ is the COD $(\mathrm{mg} / \mathrm{L})$ degradation of the microorganisms in the mixed solution; the oxygen consumed by the microorganism as the energy the amount.

Take the $\mathrm{A}_{2} / \mathrm{O}$ process aerobic tank at the end of the activated sludge, full aeration has repeated washing with distilled water, put away the supernatant, the depletion of activated sludge in the residual dissolved COD. Dosing nitrification inhibitor $(0.2 \mathrm{mg} / \mathrm{L})$ and part of the raw water to mix well, we take appropriate amount of mixed sample flocculation process for COD determination, the results recorded as $\mathrm{COD}_{1}$. Then we can 
use BI-2000 for microbial oxygen consumption rate determination. Test for 1 day to read the BI-2000 electrolyte breathing apparatus on the oxygen consumption $\left(\int r(t) d t\right)$ and then take the appropriate amount of the product flocculation COD measured as $\mathrm{COD}_{2}$. Then $\mathrm{YH}$ is calculated as follows.

$$
\begin{gathered}
Y_{H}=\frac{\Delta C O D C \text { ell }}{\Delta C O D \text { Soluble }}=\frac{\Delta C O D-\int \mathrm{r}(\mathrm{t}) \mathrm{dt}}{\Delta C O D} \\
\triangle C O D=C O D_{1}-C O D_{2}
\end{gathered}
$$

From Table 2 we can see that the yield coefficient of heterotrophic bacteria was 0.65 , which was lower than the recommended value, 0.67 was 0.02 . It indicated that the activity of $\mathrm{A}_{2} / \mathrm{O}$ activated sludge was slightly lower and the biodegradation. The same pollutants are under the premise of its less mud production.

Table 2. Heterotrophic bacteria yield coefficient YH determination results

\begin{tabular}{|c|c|c|}
\hline Number & YH & \multirow{2}{*}{ Recommended value } \\
\hline 1 & 0.67 & \multirow{2}{*}{0.67} \\
\hline 2 & 0.66 & \\
\hline 3 & 0.61 & \\
\hline Average value & 0.66 & \\
\hline
\end{tabular}

\section{Determination of maximum specific growth rate of heterotrophic bacteria}

The oxygen consumption rate at any time in the batch reactor under the conditions of dissolved oxygen and sufficient substrate can be expressed as follows (Eq. 20).

$$
\operatorname{OUR}(\mathrm{t})=\frac{1-Y_{H}}{Y_{H}} u_{H} X_{H}(t)+\left(1-f_{p}\right) b_{H} X_{H}(\mathrm{t})
$$

It can be seen that $\mathrm{Ln}(\mathrm{OUR})$ depends on $\mathrm{XH}(\mathrm{t})$ that is the concentration of heterotrophic bacteria in the reactor at time $t$, the change of heterotrophic concentration can be expressed as follows (Eq. 21).

$$
\frac{\mathrm{d} X_{H}(\mathrm{t})}{d t}=\left(u_{H}-b_{H}\right) X_{H}(\mathrm{t})
$$

Score the above formula (Eq. 22).

$$
X_{H}(t)=X_{H}(0) \mathrm{e}^{(u H-b H) t}
$$

Equation 22 takes into Equation 20 (Eq. 23). 


$$
\ln \operatorname{OUR}(t)=\ln \left[\left(1-Y_{H}\right) / Y_{H} \bullet u_{H}+\left(1-f_{p}\right) \bullet \mathrm{b}_{H}\right] X_{H}(0)+\left(u_{H}-b_{H}\right) \bullet t
$$

The above formula shows that with $\operatorname{Ln}(\mathrm{OUR})$ as the ordinate and time $\mathrm{t}$ as the abscissa plot, the resulting slope is $(\mathrm{uH}-\mathrm{bH})$ and $\mathrm{uH}$ can be obtained under the premise that $\mathrm{bH}$ has been measured.

Take the sewage treatment plant $\mathrm{A}_{2} / \mathrm{O}$ process in the aerobic pool of mixed liquid fully aeration, during the time washed mud 3 times use of deionized water, standing to abandon the supernatant so that the sludge in the endogenous breathing level. Take the same amount of sewage from the inlet of the biochemical section of the sewage treatment plant to add to the endogenous respiration sludge after the above treatment (Liu et al., 2016). To avoid nitrification affect the consumption of heterotrophic bacteria, add nitrification inhibitor (propylene thiourea) $0.2 \mathrm{mg} / \mathrm{L}$ to inhibit the activities of autotrophic bacteria, with BI-2000 Electrolytic Respiration Tester measured OUR curve, and then ln OUR on t mapping, linear slope of $\mathrm{uH}-\mathrm{bH}, \mathrm{UH}$ has been measured under the premise of bH being measured.
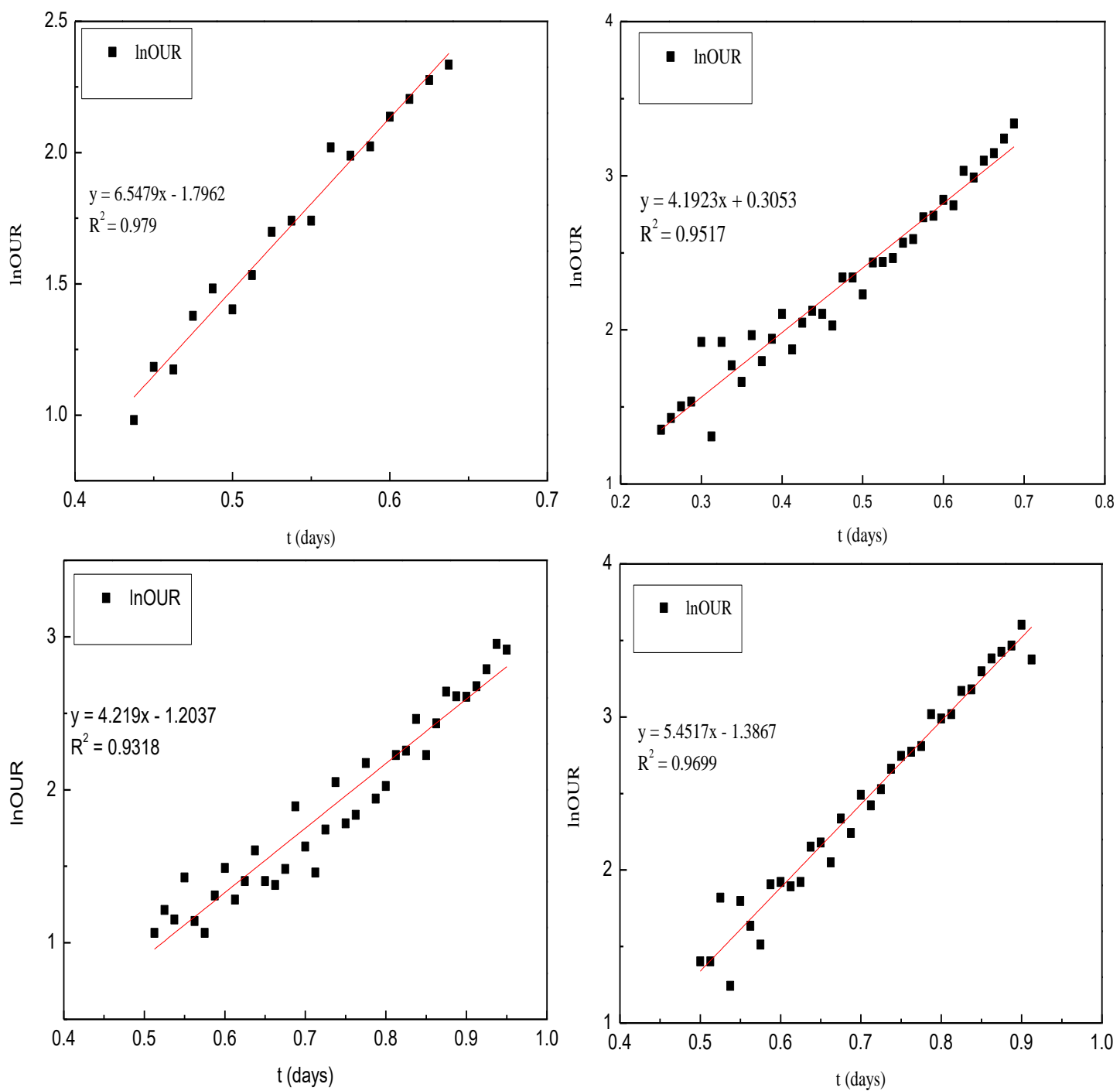

Figure 4. Maximum growth rate of heterotrophic bacteria uH measurement curve 
From Figure 4 we can see that $\operatorname{Ln}(\mathrm{OUR})$ is linearly fitted with time and the fitting degree is better. It shows that the method has some rationality. From the above equations (Eqs. 2-18), the maximum rate of growth is calculated from the slope as shown in the following table.

Table 3. Determination of the maximum specific growth rate of heterotrophic bacteria $u H$

\begin{tabular}{|c|c|c|c|}
\hline Number & $\mathbf{u H}-\mathbf{b H}$ & $\mathbf{u H}$ & \multirow{2}{*}{ Recommended value } \\
\hline 1 & 6.55 & 10.05 & \multirow{2}{*}{6} \\
\hline 2 & 4.19 & 7.69 & \multirow{2}{*}{} \\
\hline 3 & 4.22 & 7.72 & \\
\hline 4 & 5.45 & 8.95 & \\
\hline Average value & 5.10 & 8.60 & \\
\hline
\end{tabular}

From Table 3 it can be seen that the results of the maximum specific growth rate of heterotrophic bacteria show that the use of BI-2000 electrolyte respiration rate analyzer, the range is large and the range is roughly $7.72 \mathrm{~d}-1-10.05 \mathrm{~d}-1$, the average is $8.6 \mathrm{~d}-1$ compared with ASM1 model. It indicated that in the sewage treatment plant $\mathrm{A}_{2} / \mathrm{O}$ process the activity of microorganisms faster than the proliferation rate.

\section{Discussion}

(1) The factors influencing the stoichiometric parameters of heterotrophic bacteria were sludge load ratio and temperature. The sludge load is too high and the sludge concentration in the reactor is small. After the reaction, some sludge sticks to the head of the aeration and the wall of the bottle so that the measured Cell COD increase is too small; resulting in $\mathrm{YH}$ value is too small. When the sludge load is too low, the dissolved $\mathrm{COD}$ in the reactor has been consumed at the end of the reaction. At this time, the sludge may be in the endogenous respiration stage and does not reflect the actual sludge growth, so the measured YH value will be small.

(2) The biomechanical parameters and stoichiometric parameters of microbes have measured by BI-2000 microbiological respirometer. However, the attenuation coefficient and maximum specific growth rate of the measured heterotrophic bacteria were larger than those of the recommended value were. The uses of this method for microbial dynamics parameters and stoichiometric parameters have some limitations. In addition, the test process did not explore the sludge load ratio and temperature on the determination of the results so this is the future use of the method of the workers Provide the direction of research.

\section{Conclusions}

Study the mixture in the $\mathrm{A}_{2} / \mathrm{O}$ process system by $\mathrm{BI}-2000$ Electrolyte Respiration Tester. The $\mathrm{YH}$ was 0.65 , the $\mathrm{uH}$ was $8.6 \mathrm{~d}^{-1}$ and the $\mathrm{bH}$ was $3.5 \mathrm{~d}^{-1}$. Experiments show that there are some differences in the relevant kinetic parameters of heterotrophic bacteria in different areas and different processes. It is suggested that in the future mathematical model construction, the measured value should be adopted when the experimental conditions permit. In addition, the kinetic parameters of sewage in 
different areas will vary greatly, especially in different catering countries. When choosing references, try to refer to relevant experimental results in this area.

Acknowledgements. This work was supported by Science and Technology Service Network Initiative, Chinese Academy of Science (KFJ-SW-STS-175) and West light project of Chinese Academy of Science (Y5C5021100), and Youth Innovation Promotion Association CAS (2016331).

\section{REFERENCES}

[1] Domingo-Félez C, Calderó-Pascual M, Sin G, et al. (2017): Calibration of the NDHA model to describe $\mathrm{N} 2 \mathrm{O}$ dynamics from respirometric assays[J]. - arXiv preprint arXiv:1705.05962.

[2] Domingo-Félez, C., Pellicer-Nàcher, C., Petersen, M. S., Jensen, M. M., Plósz, B. G., Smets, B. F. (2017): Heterotrophs are key contributors to nitrous oxide production in activated sludge under low $\mathrm{C}$-to-N ratios during nitrification-Batch experiments and modeling. - Biotechnology and Bioengineering 114(1): 132-140.

[3] Dorado, A. D., Dumont, E., Muñoz, R., Quijano, G. (2015): A novel mathematical approach for the understanding and optimization of two-phase partitioning bioreactors devoted to air pollution control. - Chemical Engineering Journal 263: 239-248.

[4] Guimerà, X., Dorado, A. D., Bonsfills, A., Gabriel, G., Gabriel, D., Gamisans, X. (2016): Dynamic characterization of external and internal mass transport in heterotrophic biofilms from microsensors measurements. - Water Research 102: 551-560.

[5] Karanasios, K. A., Vasiliadou, I. A., Tekerlekopoulou, A. G., Akratos, C. S., Pavlou, S., Vayenas, D. V. (2016): Effect of $\mathrm{C} / \mathrm{N}$ ratio and support material on heterotrophic denitrification of potable water in bio-filters using sugar as carbon source. - International Biodeterioration \& Biodegradation 111: 62-73.

[6] Leyva-Díaz, J. C., González-Martínez, A., González-López, J., Muñío, M. M., Poyatos, J. M. (2015): Kinetic modeling and microbiological study of two-step nitrification in a membrane bioreactor and hybrid moving bed biofilm reactor-membrane bioreactor for wastewater treatment. - Chemical Engineering Journal 259: 692-702.

[7] Liu, H., Chen, N., Feng, C., Tong, S., Li, R. (2017): Impact of electro-stimulation on denitrifying bacterial growth and analysis of bacterial growth kinetics using a modified Gompertz model in a bio-electrochemical denitrification reactor. - Bioresource Technology 232: 344-353.

[8] Liu, T., Ma, B., Chen, X., Ni, B. J., Peng, Y., Guo, J. (2017): Evaluation of mainstream nitrogen removal by Simultaneous Partial Nitrification, Anammox and Denitrification (SNAD) process in a granule-based reactor. - Chemical Engineering Journal 306: 973981.

[9] Liu, Y., Peng, L., Ngo, H. H., Guo, W., Wang, D., Pan, Y., et al. (2016): Evaluation of nitrous oxide emission from sulfide-and sulfur-based autotrophic denitrification processes. - Environmental Science \& Technology 50(17): 9407-9415.

[10] Mampaey, K. E., Beuckels, B., Kampschreur, M. J., Kleerebezem, R., Van Loosdrecht, M. C. M., Volcke, E. I. P. (2013): Modelling nitrous and nitric oxide emissions by autotrophic ammonia-oxidizing bacteria. - Environmental Technology 34(12): 15551566.

[11] Mozumder, M. S. I., Garcia-Gonzalez, L., De Wever, H., Volcke, E. I. (2015): Effect of sodium accumulation on heterotrophic growth and polyhydroxybutyrate (PHB) production by Cupriavidus necator. - Bioresource Technology 191: 213-218.

[12] Peng, L., Liu, Y., Sun, J., Wang, D., Dai, X., Ni, B. J. (2017): Enhancing immobilization of arsenic in groundwater: A model-based evaluation. - Journal of Cleaner Production 166: 449-457. 
[13] Peng, L., Sun, J., Liu, Y., Dai, X., Ni, B. J. (2017): Nitrous oxide production in a granulebased partial nitritation reactor: a model-based evaluation. - Scientific Reports 7: 45609. DOI: $10.1038 /$ srep45609.

[14] Pisoeiro, J., Galvão, A., Pinheiro, H. M., Ferreira, F., Matos, J. (2017): Determining stoichiometric parameters of detached biomass from a HSSF-CW using respirometry. Ecological Engineering 98: 388-393.

[15] Qin, W., Li, W., Zhang, D., Huang, X., Song, Y. (2016): Ammonium reduction kinetics in drinking water by newly isolated Acinetobacter sp. HITLi 7 at low temperatures. Desalination and Water Treatment 57(24): 11275-11282.

[16] Smriga, S., Fernandez, V. I., Mitchell, J. G., Stocker, R. (2016): Chemotaxis toward phytoplankton drives organic matter partitioning among marine bacteria. - Proceedings of the National Academy of Sciences 113(6): 1576-1581.

[17] Wang, Q., Ni, B. J., Lemaire, R., Hao, X., Yuan, Z. (2016): Modeling of nitrous oxide production from nitritation reactors treating real anaerobic digestion liquor. - Scientific Reports 6: 25336. DOI: 10.1038/srep25336.

[18] Wu, J., He, C., van Loosdrecht, M. C., Pérez, J. (2016): Selection of ammonium oxidizing bacteria (AOB) over nitrite oxidizing bacteria (NOB) based on conversion rates. - Chemical Engineering Journal 304: 953-961.

[19] Wu, X., Yang, Y., Wu, G., Mao, J., Zhou, T. (2016): Simulation and optimization of a coking wastewater biological treatment process by activated sludge models (ASM). Journal of Environmental Management 165: 235-242.

[20] Xu, X. J., Chen, C., Wang, A. J., Ni, B. J., Guo, W. Q., Yuan, Y., et al. (2017): Mathematical modeling of simultaneous carbon-nitrogen-sulfur removal from industrial wastewater. - Journal of Hazardous Materials 321: 371-381.

[21] Yang, S. S., Pang, J. W., Guo, W. Q., Yang, X. Y., Wu, Z. Y., Ren, N. Q., Zhao, Z. Q. (2017): Biological phosphorus removal in an extended ASM2 model: Roles of extracellular polymeric substances and kinetic modeling. - Bioresource Technology 232: 412-416.

[22] Yuan, J., Dong, W., Sun, F., Li, P., Zhao, K. (2016): An ecological vegetation-activated sludge process (V-ASP) for decentralized wastewater treatment: system development, treatment performance, and mathematical modeling. - Environmental Science and Pollution Research 23(10): 10234-10246.

[23] Zięba, B., Janiak, K. (2017): Encouraging “K” Strategy Nitrifiers over "r" Strategists in Bioaugmentation Reactor. - In: Kaźmierczak, B., Kutyłowska, M., Piekarska, K., TruszZdybek, A. (eds.) E3S Web of Conferences (Vol. 17, p. 00101). EDP Sciences, Boguszów-Gorce. 